\title{
Beyond Sustainability Communication: Sustainability-integrated Corporate Communications
}

\author{
Angela Bittner-Fesseler \\ SRH Fernhochschule - The Mobile University \\ Johann Ferdinand Weicht
}

Research on sustainable communication is mostly limited to sustainability communication without presenting a model of sustainable communication itself. As this article argues, two things can happen if communication itself does not follow the principles of sustainability: Sustainability communication will be less credible, and society will overlook the cornerstone of how to address and overcome discrepancies between corporate behaviour and corporate communicative behaviour. The fact that earth's natural resources are limited, is not yet incorporated in corporate communication as practised by organisations. At the borders of sustainability and communication this paper therefore argues for the development and implementation of sustainability-integrated corporate communications.

Keywords: corporate communication, sustainable communication, sustainability-integrated corporate communications

\section{INTRODUCTION}

Unlike the energy sector, mobility, agriculture, and resource conversation, communication has not been identified as one of the key areas of action (for the strategic fields see Rogall, 2012, p.127) and strategy in the sustainable economy - despite the fact that society and companies are increasingly addressing environmental issues. Communication, however, is as central to human society as energy and any other resource because of its relevance in shaping world perceptions. Corporate communication is involved in almost every act of business. However, it is usually granted only a supportive, rarely a strategic role.

Today's German research on sustainable communication is limited either to sustainability communication or to everyday definitions of characteristics that communication should or could have, without presenting a convincing model of sustainable communication. In the past ten years, there have been fundamental discussions on this relatively recent topic in the German research landscape, in which definitional approaches have been developed (cf. Michelsen \& Godemann, 2007; Prexl, 2010; Brugger, 2010; Raupp, Jarolimek \& Schultz, 2011; Prüne, 2013; Heinrich \& Schmidpeter, 2013 \& 2018). The starting point for the authors of this article is the constitutive role that communication plays in the existence of corporations, which leads to a dialectical coherence: if corporate communication itself does not follow the ideas and principles of sustainability, i.e. if communication is not designed sustainably, the credibility of this central implementation resource of Sustainable Economics ${ }^{1}$ is lost. This includes, for 
example, the potential to realise sustainable action and to gain resonance and acceptance for such behaviour. This outlines the potential of communication. To date, however, there is no scientific approach for this.

\section{THE ROLE OF COMMUNICATION IN BRINGING ABOUT SUCCESS FOR THE SUSTAINABLE ECONOMY}

Social coexistence and thereby society arise where communication between people is successful. The need for communication is based on the fact that through communication people not only create their relationships to each other but also determine the meaning, function and relation of things. Communication is the conveyance of information between people with the goal of establishing shared understanding. With the help of this common symbolic world, actors can explain themselves, agree to shared actions, and reach consensuses (in summary here cf. for example Ziemann, 2007, p.124; Hargie, 2013, p.35). These shared meanings play an elementary role in the social life of humans, as they allow people to name things, but also to plan, justify, and construct their meanings. In this human reality, concepts such as "tree", "water", but also the term "sustainable" are symbolic. Since a construction of meaning emerges precisely through this human communicative exchange over time, it is a subject of public discourse and at the same time it is subject to constitutive change. Thus, shared meaning and knowledge of concepts such as "sustainable" and "sustainable action" arise over a period of time and can develop and transform. In addition, the common understanding of terms can also - and this is relevant for this article - be intentionally developed further.

In the beginning is the communication. It 'creates' content. Organisations, more specifically corporations, carry certain characteristics and are thus responsible for how they communicate with regards to content, form, and implementation. This process is based on the self-understanding of any organisation and its realisation thereof. Almost twenty years ago, this underlying constructivist approach became known as the theoretical perspective of "Communication constitutes Organization", which regarded organisations as social structures produced through interaction (cf. Nicotera \& Putnam, 2009).

Communication plays an equally essential role for companies. At the macro level of society, corporate communication is constantly negotiating the recognition and legitimacy of a company's existence, as well as its integration into society. Communicative action, as well as the hearing and consideration of stakeholder claims, are vital if this is to be successful (see Post, Preston \& Sachs, 2012, p.17 on licence to operate and legitimacy). Communicative action is perceived as authentic and credible, if the actions of a company match with their communicated self-representation in the eyes of the observer. Only by sustainably designing and realising communication can a company succeed in implementing sustainability for and within itself. Communication, therefore, becomes a necessary component of sustainability. This type of sustainable communication has the potential to change the company itself: "If communication is a social process in which community orientation, mutual control, and informative communicative action takes place, communication is to be understood as a socializing principle, whereby the 'inside' comes to the 'outside"' (Ziemann, 2007, p.124). The rarity / non-existence of this consistently sustainable approach to communication means that there is a need for a discussion of sufficient criteria for sustainable communication that clearly characterise the scope, content, direction, and nature - i.e. the modes and formats - of corporate communications. It is necessary to develop corresponding guiding principles, inasmuch as meanings structure everyday knowledge and perception through instrumentalization and socialisation processes. Thus, meanings obtain a normative, "objective force" (Brand, 2007, p.153). Anchored societal interpretations and practices, however, need constant communicative reproduction to provide orientation and to exercise its normative function (ibid.). Thereby sustainability-oriented guiding principles for corporate communications can become strong recommendations for action. This would at first focus on the characteristics of corporate communications and the values behind them and even more initiate communication about what sustainable communication is and should be. 
As interpretations that become dominant in public discourse make certain institutional forms of regulation appear appropriate, the way to enforce sustainable communication can be through public communication. This way, opposed actions, such as the excessive consumption of natural resources, consequently become inappropriate or illegitimate. This requires frames which mobilise and resonate with audiences and succeed in calling into question the previous prevailing practices (Brand, 2007, p.155). As a result, new norm-building processes and a restructuring of social reality and institutional practices take place: The true potential of sustainable communication is that new rules of human coexistence are conveyed to and learned by people through socialisation processes. These new rules influence people's plans, expectations, communication options and expressions. If socio-cultural structures and situational rules are not only confirmed and preserved through communication, but are continuously redesigned, extended, and optimised, communication itself and, by extension, society will be transformed.

Another observation also plays a crucial role in this article. In the general understanding, sustainability communication and sustainable communication are usually used synonymously. Both sustainability communication and sustainable communication are understood as a deliberative cultural technique that should be dialogical, transparent, authentic, and effective. The common interchangeability of both terms points is a display of the still missing theoretical embedding of sustainability in corporate communications. In light of the broader developments of sustainability within society and corporations, it has become necessary to clearly distinguish the two terms, and to define what is meant by sustainable communication. This article therefore proposes a firm distinction between sustainability communication and sustainable communication, in the sense of an etymological or meaning-defining conceptual approach with attributed characteristics.

One of the peculiarities of corporate communications in the context of sustainability is that it serves a double role. On one hand, corporate communication reports companies' sustainability behaviour and thus contributes to their legitimacy and reputation (sustainability communication as a field of action within corporate communications). On the other hand, corporate communications should support sustainable action as part of corporate services and strategy (sustainability communication as a role of functional public relations). The new, third dimension is for communication to be sustainable in itself. This has not been considered in research and practice.

This article therefore discusses relevant sustainability theories with regard to communication, to arrive at a new, and above all, practicable approach and understanding of sustainable corporate communications. First, the concept of sustainability communication, as used in the German-language specialist literature, will be delimited, which deals with future-proofing societal development and is centred on the guiding principles of sustainability (cf. Michelsen, 2007; Raupp, Jarolimek \& Schultz, 2011; also Heinrich, 2013 \& 2018; as well as dissertations Brugger, 2010; Prexl, 2010; Prüne, 2013, traditional as Crane, 2009). In an early definitional attempt, published in the Handbook of Sustainability Communication (Michelsen, 2007, p.27), Michelsen describes this process as dealing with values such as inter- and intra-generational justice, a causal investigation and the perception of problems, and individual as well as societal courses of action.

Also in 2007, Mast and Fiedler pointed out that the concept of sustainable corporate communication is still to be defined, considering the diverse approaches and views that have been published up until this point (Mast \& Fiedler, 2007, p.569). They assume that this is partly due to the complexity of sustainability and the fact that sustainability is multidimensional, albeit attempting to treat the TripleBottom-Line's three dimensions equally (ibid. p.570). Mast and Fiedler deem it necessary to simplify the flood of information surrounding sustainability, although it may lead to different understandings of the term by different people. According to Mast and Fiedler, companies also seek a dialogue with society based on the understanding that corporate interests and social responsibility cannot be separated; they refer to the first Handbook of Sustainability Communication, whose theory is based mainly on functional characteristics such as a profiling function, competitive advantages, benefits in employee motivation and the reduction of competitive disadvantages and risks (Mast \& Fiedler, 2007, p.569ff.).

Three years later, Brugger also points to the functions and benefits of sustainable communication for companies (Brugger, 2010, p.236). He stresses that corporate sustainability communication has a strong 
societal and economic focus and can only be practised by companies that have a strong commitment to sustainability. This is due to sustainability-oriented corporate governance and is thus closely linked to a company's products and services. The sustainability performance of a company is communicated to society and the market at great expense, in order to bring about social legitimation and transformation, to create a competitive differentiation, and to promote sustainable organisational development. Brugger defines the following criteria as essential for a model of corporate sustainability communication: dialogue orientation, target audience orientation, the ability to integrate and to ensure a holistic representation of the three sustainability dimensions as well as integrated communication measures (Brugger, 2010, p.238239).

Another publication uses the simile "communicating sustainability - communicating sustainably" (Nachhaltigkeit kommunizieren - nachhaltig kommunizieren) but lacks the necessary amount of differentiation in several ways. Firstly, from a content perspective, sustainability is seen as an integrative topic of public relations, i.e. sustainability communication means the integration of sustainability issues in the overall communication. Secondly, from a functional point of view, sustainability communication is considered to be strategically important for achieving organisational goals. Thirdly, sustainability communication can contribute to the achievement of the organisational and, in particular, sustainability goals. Lastly, sustainability communication is also considered normatively, i.e. the societal potentials of corporate sustainability communication (such as sensitisation, contributing to economic and social awareness of sustainable development) are coming to the fore (Prexl, 2010, p.21-22).

A 2013 specialised publication examining the sustainability communication of luxury fashion brands also primarily focuses on its function for companies (Prüne, 2013, p.376): Prüne considers the objective to be focussed on the socio-political sphere of public relations, and develops a market-oriented sustainability communication, which uses this socio-ecological orientation as a competitive advantage and to boost sales.

The recently published second edition of the thematic anthology "CSR and Communication: Convincingly Communicating Corporate Responsibility" (Heinrich \& Schmidpeter 2018, p.3; 19) also primarily focusses on the sustainable communication as a function of communicating corporate activities and commitment.

One of the few attempts to actually characterise sustainable communication as sustainable comes from Ternés. In the digital Gabler's Economic Lexicon, she links sustainable communication with economic and managerial topics to achieve a resource-oriented form of communication, which is characterised by appreciation, respect and honesty in relation to the interlocutor and aims at a long-term relationship (Ternés, 2018); thereby explicitly considering the characteristics of communication such as authenticity, transparency, dialogue orientation, empathy and stakeholder orientation, with the aim of working for mutual benefit based on the principle of long-term success. However, the character of communication remains unspecified. In today's corporate communications, such qualities are considered crucial to the success of communications and lead towards effective corporate communications, as defined by modern organisations and businesses. Relevant overviews of corporate communications usually say that communication tools flank a company-wide corporate sustainability program or communication complements sustainable corporate governance but cannot replace it. (cf. Mast, 2016, p.479-504).

\section{CORPORATE COMMUNICATION'S DUAL ROLE IN SUSTAINABILITY}

Corporate communication plays a dual role in sustainability: on the one hand, companies inform about their sustainability performance and, on the other hand, corporate communication should be geared towards supporting a company's sustainability efforts. In order to point out how the integration of sustainability into corporate communications can succeed, we shall, at this point, transfer relevant approaches to sustainability to the field of communication.

The model of the Triple-Bottom-Line, i.e. the consideration of economic, ecological and social aspects, still shapes the political and corporate debate on sustainability today. The German Bundestag 
defines sustainability as the equal and equivalent consideration and treatment of these three aspects - but can they be understood that way? We know that planet earth is finite, both in its spatial extent and in terms of its natural resources. And physically speaking, it is impossible for any subsystem within a finite system to grow infinitely (Jackson, 2017, p.21). The British author and former Economics Commissioner of the UK Sustainable Development Commission Tim Jackson therefore fundamentally questions the economy's growth dogma and states that, in order for every person to have an income equal to that of wealthy western states, the world economy would need to be thirty times more productive by the end of the twenty-first century than it is today (Jackson, 2017, p. 20). Such growth is however hard to imagine due to the very premise that the earth's natural resources are limited. Jackson's work culminated in 2009's publication of the study "Prosperity without growth?", which was published as a stand-alone book one year later (revised version Jackson, 2017).

Holger Rogall's equally relevant work "Sustainable Economy" emphasises, similar to Jackson, that the current development of humankind is unsustainable, and introduces the concept of strong sustainability (Rogall, 2012). The German researcher stresses that the economy is a subsystem of nature and that natural resources are largely un-substitutable. The Triple-Bottom-Line, which assumes an equivalence of the target dimensions (without absolute natural boundaries), is thus rejected and instead the absolute boundaries of nature are recognised (Rogall, 2012, p.124; see also the more complex model of Raworth, 2019). The focus is on the long-term conservation and not the optimal use of natural resources. At the center of the ongoing debate, Rogall saw how sufficient ecological, economic and sociocultural standards can be achieved within the limits of natural sustainability and the principle of intra- and intergenerational justice can be realised (ibid., p.125; see also Umbach \& Rogall, 2013, p. 7ff.). This article is therefore based on Jackson's and Rogall's understanding of sustainability.

Assuming a strong sustainability according to the primacy of finite nature, one question remains unanswered, what about the social aspect of sustainability? In addition to the discussion of the interaction between economy and ecology, the effects of economic activities on the psyche of the individual and on social phenomena has already been discussed intensively in research. Jackson defines role of the economy in that it should enable and deliver prosperity, whereby the underlying concept of said term goes far beyond material wealth. It describes an individual's ability to thrive physically, psychologically, and socially, as well as the importance of social and societal participation once basic needs are satisfied (Jackson, 2017, p.121). Looking at the social well-being of an individual, one quickly encounters a central starting point: Georg Franck's The Economy of Attention. In his fundamental work from the end of the 1990 s, Franck describes attention as the interplay of the basic capacity of perception (awareness) and the presence of mind in the form of the targeted paying of attention, thus defining attention as a relevant and equally limited human resource (Franck, 1998, p.28-30, see also Franck, 2014). In Franck's sense of the term, attention describes the limited ability of the human being to consciously process and experience, which is required for all thought processes without exception (Franck, 1998, p.49-51). The capacity of the individual to experience psychological well-being and social participation is therefore limited. The flood of information generated by the constant growth of what attention can be spent on, forces us to be economise with this precious resource (ibid.). The psychological symptom of an overly strained processing capacity manifests itself as stress; the inadequate processing as hecticness (Franck, 1998, p.50). As a result, carelessly economising attention does not only directly reduce mental wellbeing, it also lowers the amount of attention that can be turned towards prosperity in its physical, psychological, and societal qualities. Based on Jackson's understanding of the role of the economy and Franck's economics of attention, the economy must also be understood as a subsystem of the social dimension of sustainability. The attribute of modern communication, which the German sociologist and social theorist Niklas Luhmann described as a no longer ignorable, disturbing noise of human communication also belongs in this context (Luhmann, 2004, p.12).

It can thus be concluded that the equivalence of economic, ecological and social sustainability criteria is not convincing in the context of communication - neither from an environmental nor a social perspective, as the environmental and social aspects of sustainability are more valuable. With boundless economic growth, natural resources and the social processing resource attention become increasingly scarce. The avoidance of this state cannot be realised on the demand side alone: the construct of the homo 
oeconomicus, the rational man, who chooses the most advantageous offer that fulfils the expected benefit, shows that, within the prevailing economic system, it will be difficult to move towards a sustainable economy as long as social and environmental costs are externalised, and pricing is displaced accordingly. Likewise, increases in efficiency in the production and use of products do not necessarily lead to an overall lower consumption of resources, which is also as a rebound effect (cf. Umweltbundesamt 2014).

\section{RETHINKING THE ATTRIBUTES OF CORPORATE COMMUNICATION}

A comprehensive understanding of sustainability must therefore consider economics as a subsystem of society and the environment. This also becomes the premise of sustainable communication. The starting point is a holistic concept of communication, that understands corporate communication as a superordinate term for the communication of companies with all internal and external stakeholders, ranging from market-oriented communication with potential customers to communication with employees, public and civil society organisations, press and media, as well as other interest groups. Corporate communication already knows the concept of holistically integrating communication, which describes the alignment of all communication in content, form and time, and serves to increase the effectiveness of communication. If we now assume the sustainable development and action of companies and organisations as our framework and specify it so that economic activities should only work within social and environmental boundaries, it should be possible to derive statements about the conditions of sustainable communication.

Regarding the environmental dimension of sustainability, both the resources required for communication and the resource use of the products and services themselves must be taken into account along the entire communicative realisation process. It is important to consider the content as well as the forms and processes of communication:

1. Firstly, this includes the sustainable design of the physical and energetic nature of the respective form of communication.

2. Secondly, communication must be about products and services whose use of resources move within social and environmental limits and which are considered to be particularly efficient.

3. Thirdly, the information should be designed in such a way that attracts recipients' attention towards sustainable products and services. On the social level, this requires that the recipients' attention is recognised as an increasingly scarce resource. It also means that too much information is a risk factor for mental well-being.

So, if one disagrees with the neo-classical or economic-liberal economy view on the primacy of the economy, the dogma of consumer sovereignty, and the equal coexistence of the three dimensions of sustainability, one must also rethink corporate communication (cf. Rogall, 2012, p.109-110). This process of reframing leads towards the rejection of a style of corporate communication that accepts a maximum consumption of natural and social resources in order to achieve its goals.

We therefore propose the concept of sustainability-integrated communication, that uses the concept of integrated communication to implement sustainability in corporate communications. Communicative behaviour in its entirety (i.e. instruments, channels/media, time choice/interval, content) shall adapt the understanding of sustainability outlined in this article. The integration is considered complete when a company's sustainability strategy is based on the underlying understanding of sustainability, and its communication is equally aligned.

\section{DEFINING SUSTAINABILITY-INTEGRATED COMMUNICATION}

Every single company influences societal processes by communicating about corporate activity and responsibility. This makes sustainability communication part of business ethics practice and, through the sustainability paradigm, ideally generates a positive global impact (Bittner \& Warnhoff, 2016, p.164 in terms of SME; Lock \& Seele, 2016 in terms of CSR reports). At the same time, sustainability-integrated communication must balance a potential overemphasis of the relevance of communication and the fact that sustainable action without communicative facilitation is hardly imaginable. Because people are 
moving in affective-cognitive reference systems, sustainability-integrated communication should not be taught, it rather should be designed and experienced in an informed way. A life within planetary boundaries is not achieved by the illusion of the possibility of doing nothing, but by informed, scientifically supported and thus interventional decisions (Janich 1996, p.199, cit. after Siebert 2007, p.142). Sustainability-integrated communication can act as a decision-making frame with criteria for the assessment of future projects and organisational goals, thereby making sustainability-integrated communications an output-oriented programme of purpose, part of a company's self-perception and a self-evident part of corporate communication. The implementation of the concept of sustainability in communication necessitates its operationalisation and requires new indicators and suitable targets (see generally Rogall, 2012, p.126), whose development is still pending. In addition, an equally pending discussion of communication instruments would have to:

1. factor in the limitation of natural and social resources in the conception of communication and in the planning of measures; and

2. be acceptable as a practical way of thinking. This includes:

a. practically applicable and implementable evaluation criteria for the selection, conception and implementation of communication measures. This can be implemented in a transformational design, as the cultural genesis is a more changeable state in the form of the factuality of current infrastructures and past conditions of action. It is the transformation of cultural practices of the use of energy, substances, products and thus social categories such as communication, commerce, consumption and supply (Sommer \& Welzer, 2014, p.115). Transformation design uses the least possible effort. This can also be nil (Sommer \& Welzer, 2014, p.114).

b. An equally central dimension is the content-related integration of sustainability into corporate communications. In other words, communication that enables and supports sustainable action within a company by assessing, selecting and implementing the content and message of communication based on sustainability criteria.

As a result, communication can be a process aimed at creating mutual understanding, which is based on an attribution that people share and requires the following criteria as a prerequisite for its success: content (product/service/production), message, form (means of transport) and the effect. To visualise this, think of the following scenario:

Based on information and knowledge, a person decides to reduce their consumption as a whole and to buy their groceries sustainably, i.e. regional, seasonal, organic, and biodiverse. This resembles a company changing its operations to become more sustainable. (Content)

He or she know tells their friends and acquaintances about their new lifestyle. (Message)

But their means of transportations shows something else - because they drive a SUV with a high diesel consumption. Therefore, this dimension of their lifestyle has not been sustainability integrated. Of course, their friends notice this discrepancy and do not understand it. (Form)

This scenario resembles a company which would like to become more sustainable and therefore changes certain things within its own boundaries and their supply chain. However, the company does not consider that many of the touch points people have with their company come from direct experience, nor is all information verifiable. Instead, people primarily experience the company through the company's owned media, paid media, or earned media, that all have their own character - e.g. printed in bulk on chlorine-bleached paper and randomly distributed to hundreds of thousands just to be thrown away. Ergo, the messages attributed to the chosen media do not match the ones corporate communication is trying to convey. (Effect) 
Of course, this scenario can also be used to illustrate a communication that is not sustainability integrated in terms of its content. Imagine a communication that can be considered (more or less) sustainable regarding its form, e.g. a billboard campaign printed on certified paper. However, what is being advertised is the aforementioned SUV with high diesel consumption. Again, there is a discrepancy between corporate action and communication, which thwarts the company's sustainability efforts and is therefore not credible.

A company's sustainability profile is credible only if it runs through all corporate activity - also including the entire external and internal communication. In this regard, a discussion of the criteria for sustainability as well as the definition of sustainability of communication are overdue. Regarding the management principles of Sustainable Economics, the principle of responsibility, solidarity inter- and intra-generational justice, and the recognition of planetary boundaries; these criteria cannot be detached from the scientific debate about the effect, efficiency and characteristics of communication in today's scientific discourse of public relation.

Knowledge alone is not sufficient for this; target knowledge or orientation knowledge must be available and designed as system knowledge based on new values with ethical orientation in the relationship between man and nature. With the change towards sustainability-integrated communication comes a synchronisation of knowledge, attitudes, and actions, so that this new form of communication becomes the benchmark. The new dimension of corporate communication - being sustainable - can then also be incorporated into the code of communicators: not only as an ethical appeal, but also in order to be effective and credible with doubled self-interest. As a result, corporate communication could establish itself as an important field of action for sustainability and in the wider sustainability debate.

Sustainability-integrated corporate communication is rarely practiced today, which is often explained because of the management rejecting it - a reason that can be invalidated with the right knowledge and value system. Moreover, there is too little attention paid to the ecological and social dimension of massive, short-term oriented, superficial, devoid of meaning, or ethically questionable - thus needless communication.

Assuming that companies are constituted through communication, and that their own identity and culture as well as their reputation and brand image are largely based on communication processes (same applies to a time changed by digitisation see Zerfass \& Pleil, 2015, p.45), it is a requirement to establish sustainability-integrated communication in companies: firstly, to act sustainably and to ensure the credibility of the company's actions. And secondly, to re-integrate companies into the changing society, thereby securing their future existence.

It must be clearly emphasized that sustainability-integrated communication is an opportunity and not a new form of cost reduction. It is based on the recipients' benefits and works according to the appropriateness principle as is the case in other industries, too. This requires the idea and description of sustainability-integrated communication to be discussed and worked out now.

\section{REFERENCES}

Brand, K-W. (2007). Nachhaltigkeitskommunikation: eine soziologische Perspektive. In G. Michelsen, J. Godemann, (eds.). Handbuch Nachhaltigkeitskommunikation. Grundlagen und Praxis, (2nd ed., 151-161). München: oekom verlag.

Brugger, F. (2010). Nachhaltigkeit in der Unternehmenskommunikation. Bedeutung, Charakteristika und Herausforderungen. Wiesbaden: Gabler Verlag.

Crane, A. (ed.) (2009). The Oxford Handbook of Corporate Social Responsibility. Oxford: Oxford University Press.

Franck, G. (1998). Ökonomie der Aufmerksamkeit. Ein Entwurf. München: Carl Hanser Verlag.

Franck, G. (2014). Jenseits von Geld und Information: Zur Ökonomie der Aufmerksamkeit. In A. Zerfaß and M. Piwinger (eds.). Handbuch Unternehmenskommunikation. Strategie - Management, 193202. Wiesbaden: Springer Gabler.

Heinrich, P. (ed.). (2013). CSR und Kommunikation: Unternehmerische Verantwortung überzeugend vermitteln. Berlin: Springer Gabler. 
Heinrich, P., \& Schmidpeter, R. (2018). Wirkungsvolle CSR-Kommunikation - Grundlagen. In P. Heinrich (ed.). CSR und Kommunikation, Unternehmerische Verantwortung überzengend vermitteln, (2nd ed., 1-25). Berlin: Springer Gabler.

Jackson, T. (2017). Prosperity without growth: foundations for the economy of tomorrow, (2nd ed.). Abingdon, New York: Routledge.

Lock, I., \& Seele, P. (2016). The Credibility of CSR Reports in Europe. Evidence from a Quantitative Content Analysis in 11 Countries. Journal of Cleaner Production, 122, 186-200.

Luhmann, N. (2004). Ökologische Kommunikation. Kann die moderne Gesellschaft sich auf ökologische Gefährdungen einstellen? (4th ed.). Wiesbaden: VS Verlag für Sozialwissenschaften.

Mast, C. (2016). Unternehmenskommunikation, (6th ed.). Konstanz, München: UTB.

Mast, C., \& Fiedler, K. (2007). Nachhaltige Unternehmenskommunikation. In G. Michelsen and J. Godemann (ed.). Handbuch Nachhaltigkeitskommunikation. Grundlagen und Praxis, (2nd ed., 567-578). München: oekom verlag.

Michelsen, G. (2007). Nachhaltigkeitskommunikation: Verständnis - Entwicklung - Perspektiven. In G. Michelsen and J. Godemann (Ed.). Handbuch Nachhaltigkeitskommunikation. Grundlagen und Praxis. (2nd ed., 25-41). München: oekom verlag.

Nicotera, A. M., \& Putnam, L. (ed.) (2009). Building theories of organization. The constitutive role of communication. ebrary, Inc. New York: Routledge (Communication series. Organizational communication).

Post, J. E., Preston I. E., \& Sachs, S. (2002). Redefining the Corporation. Stakeholder Management and organizational wealth. Stanford: Stanford University Press.

Prexl, A. (2010). Nachhaltigkeit kommunizieren - nachhaltig kommunizieren. Analyse des Potenzials der Public Relations für eine nachhaltige Unternehmens- und Gesellschaftsentwicklung. Wiesbaden: VS Verlag für Sozialwissenschaften / GWV Fachverlage.

Prüne, G. (2013). Luxus und Nachhaltigkeit. Entwicklung strategischer Handlungsempfehlungen für das Luxusgütermarketing. Hohenheim, Univ. Diss. 2012. Wiesbaden: Springer-Fachmedien Wiesbaden.

Raupp, J., Jarolimek, S., \& Schultz, F. (eds.). (2011). Handbuch CSR. Kommunikationswissenschaftliche Grundlagen, disziplinäre Zugänge und methodische Herausforderungen. Wiesbaden: VS Verlag für Sozialwissenschaften.

Raworth, K. (2019). Doughnut Economics. Retrieved October 30, 2019, from https://www.kateraworth.com/doughnut/

Siebert, H. (2007). Nachhaltigkeitskommunikation: eine system-konstruktivistische Perspektive. In G. Michelsen and J. Godemann (ed.). Handbuch Nachhaltigkeitskommunikation. Grundlagen und Praxis. (2nd ed., 132-142). München: oekom verlag.

Sommer, B., \& Welzer, H. (2014). Tranformationsdesign. Wege in eine zukunftsfähige Moderne. München: oekom verlag.

Ternés, A. (2018). Nachhaltige Kommunikation. Retrieved April 1, 2018, from https://wirtschaftslexikon.gabler.de/definition/nachhaltige-kommunikation-53886

Umbach, E., \& Rogall, H. (2013). Nachhaltigkeit - Konkretisierung eines kontroversen Begriffs. In H. Rogall (ed.). Im Brennpunkt. Wachstum. Jahrbuch nachhaltige Ökonomie, 1.2011/2012 (2nd ed., 57-80). Marburg: Metropolis-Verlag.

Umweltbundesamt. (2014, March 14). Rebound-Effekte. Retrieved June 9, 2018, from https://www.umweltbundesamt.de/themen/abfall-ressourcen/oekonomische-rechtliche-aspekteder/rebound-effekte

Ziemann, A. (2007). Kommunikation der Nachhaltigkeit. Eine kommunikationstheoretische Fundierung. In G. Michelsen and J. Godemann (ed.). Handbuch Nachhaltigkeitskommunikation. Grundlagen und Praxis, (2nd ed., 123-133). München: oekom verlag. 